\title{
THE ISSUES OF ACCESS TO JUSTICE IN THE CASE OF DISPUTE RESOLUTION WITHIN THE INDIGENOUS COMMUNITY OF TULEHU, CENTRAL MALUKU ${ }^{1}$
}

\author{
Lidwina Inge Nurtjahyo
}

\begin{abstract}
This study is aimed to analyze how customary law is practiced in strategizing dispute settlement among the villagers. In some cases, the parties who had the disputes brought their cases to the non states intermediaries to give the best remedies that fulfill their own senses of justice. As we know in the Access to Justice approaches, the disputes could be solved not only using both with state law and non-state law. These facts showed how people doing law community members in relation to dispute resolution mechanism based on customary law from the perspective of access to justice. By applying customary law, the indigenous communities could settle their disputes and reach a solution that satisfies their sense of justice. This paper attempts to describe and analyze the mechanisms of dispute settlement within the indigenous peoples of Tulehu, Central Maluku based on their customary law. This paper is based on a research paper titled 'Customary Criminal Dispute Resolution of Indigenous Peoples in Central Maluku.' The focus of this paper is the analysis of the strategies implemented by the community members in Tulehu, Central Maluku in relation to dispute settlement mechanism based on their customary law from the perspective of access to justice.
\end{abstract}

Keywords: dispute, indigenous people, justice

\section{Introduction}

The issues of access to justice, especially in legal sector, in Indonesia came into prominence after the reformation of 1998. This stemmed not only from the changes in the political climate in Indonesia, which presented the general public opportunities to receive legal protection and justice, but also from the revival of the "rule of law" in international level as mentioned by Carothers (1998); Berenschot and Bedner ${ }^{3}$. Previously, this issue is interpreted by donor organizations and governments as an attempt to "empower the law enforcement

${ }^{1}$ This paper is a continuation and analysis of field research findings on Penyelesaian Sengketa Pidana Adat di Maluku Tengah [Customary Criminal Dispute Resolution of Indigenous Peoples in Central Maluku] by Topo Santoso, Inge Lidwina Nurtjahyo, Nathalina Naibaho assisted by Muhammad Yahdi Salampessy, Najmu Laila, Muhammad Syahrir, and Hari Prasetio on 9 -15 February 2011.

${ }^{2}$ Lecturer and researcher of Anthropology Law and Women and the Law on the Field Study of Law and Society, Faculty of Law, University of Indonesia; students of the final stage of Anthropology doctoral study program at the Faculty of Social and Political Sciences University of Indonesia.

3 Ward Berenschot and Adriaan Bedner, "Akses terhadap Keadilan: Sebuah Pengantar tentang Perjuangan Indonesia Menjadikan Hukum Bekerja untuk Semua Orang [Access to Justice: An Introduction to Indonesia's Struggle to Make the Law Work for Everyone]" in Akses terhadap Keadilan [Access to Justice], (Jakarta: KITLV, HuMa, VVI Leiden University, Epistema Institute, 2011), p. 3-38. 
agencies." After experiencing failure with empowerment which is more physical and top-down, because who are able to access legal protection is only those who have the knowledge, capital, and the dominant power relations; therefore, donors and non-governmental organizations as well as some academics who concerned, introduce a new perspective on the issue of access to justice. This new perspective is also called as the "legal empowerment of the community with bottom-up approach."

There are several methods in legal empowerment of the community with bottom-up approach e.g.: revitalization of legal aid, legal socialization In community who face access impediment to legal knowledge, legal assistance, and also further study on the mechanisms of out-of-court dispute resolution which satisfies the community's sense of justice. Efforts to study the alternative dispute resolution in indigenous community are intended to develop the community's capacity to resolve their conflicts in ways that can satisfy the local sense of justice. One of the researches on the mechanisms of out-of-court dispute resolution is "Penyelesaian Sengketa Pidana Adat di Maluku Tengah".

Why dispute resolution mechanisms out-of court will be necessary to assess? The reasons are: (1) the judicial institutions nowadays have been overwhelmed to accommodate a number of cases ${ }^{5}$; (2) community's access to the judicial institutions nowadays have been overwhelmed to accommodate a number of cases ${ }^{6}$; (3) from the perspective of community acceptance, dispute settlement based on customary law is considered to be an alternative mechanism which meets the community's requirement for a resolution that satisfies their sense of justice.

This article analyzes the strategies practiced by community members in relation to dispute resolution mechanism based on customary law from the perspective of access to justice. The customary law analyzed in this paper is that of the indigenous community in the village of Tulehu, Central Maluku.

\section{The Village of Tulehu, Harbor Area on Ambon Island}

The village of Tulehu is an area within the territory of Central Maluku. Geographically, the village of Tulehu is located on latitude $28^{0}$ north. The distance between the village of Tulehu and the northern part of the city of Ambon is 24 kilometers ${ }^{7}$.

As Tulehu is a seaside village, it has bustling major and fishing ports. The presence of these two types of ports makes Tulehu a transit city for people going

${ }^{4}$ Topo Santoso et al., "Penyelesaian Sengketa Pidana Adat di Maluku Tengah" [Customary Criminal Dispute Resolution of Indigenous Peoples in Central Maluku], Research Report, (DRPM UI, Depok, 2011).

${ }^{5}$ LeIP Research Report, 2010; Ward Berenschot and Adriaan Bedner, ..Access to Justice:...., p. 3-38.

${ }^{6}$ Thomas Carothers, Promoting the Rule of Law Abroad: In Search of Knowledge, (Washington: Carnegie Endowment for International Peace, 2006); Bappenas, Bappenas Policy Recommendation - VVI Leiden tentang Kartu Tanda Penduduk dan Akses terhadap Keadilan [VVI Leiden on Identity Cards and Access to Justice]. (Jakarta: Bappenas, 2010). Maluku],..

${ }^{7}$ Topo Santoso et al., .. [Customary Criminal Dispute Resolution of Indigenous Peoples in Central 
to and from Seram Island and other Lease islands. Beside the ports, another potential that stands out from the village of Tulehu is its tourism industry. Similar to many other areas in Ambon, the village of Tulehu has the tourism potential of a coastal area; it also has several hot springs ${ }^{8}$. Most of the population of the village of Tulehu is Muslim. The rest are Christian, Catholic, and Buddhist ${ }^{9}$.

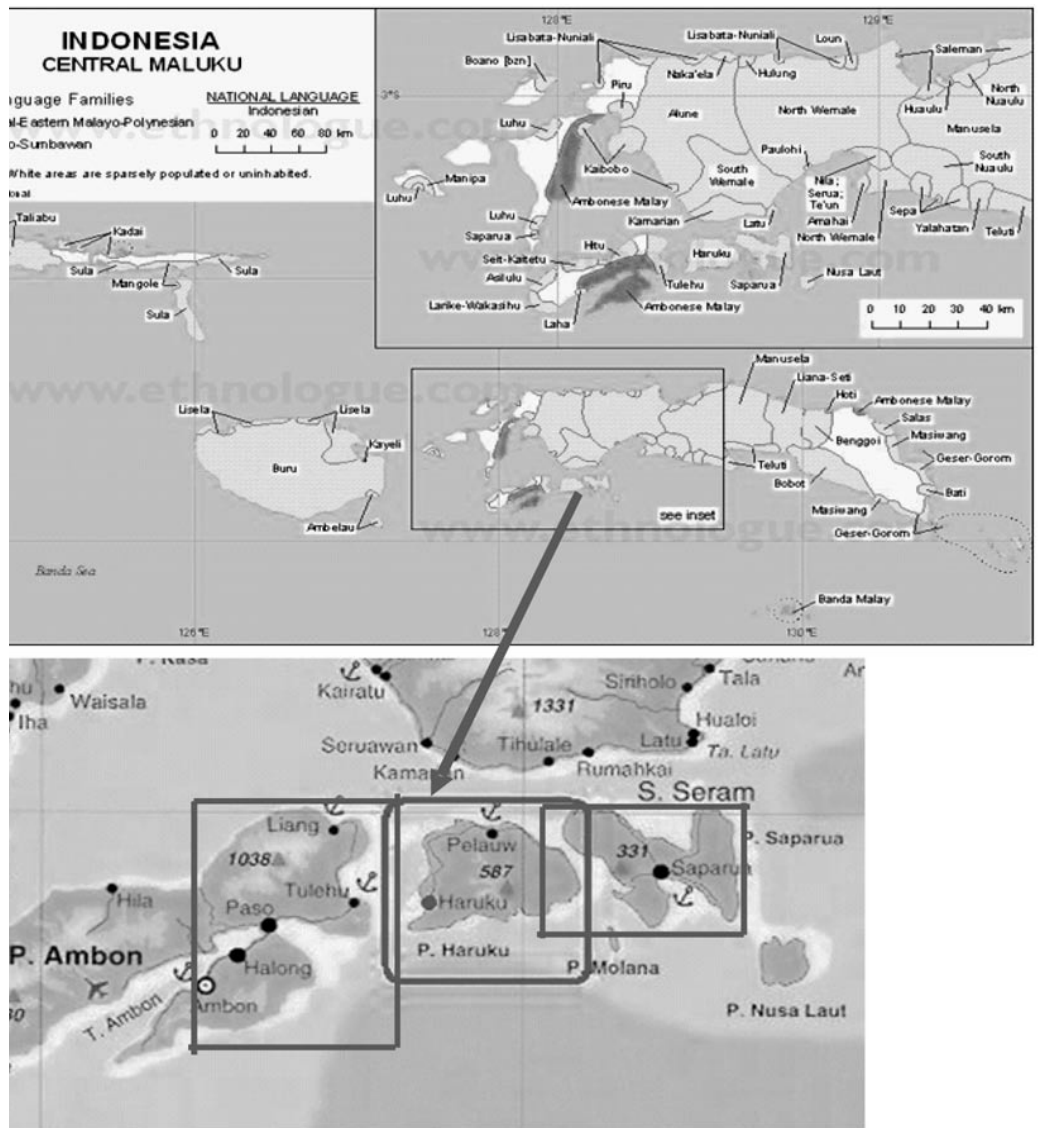

\section{The Strategy of the Community of Tulehu to Access Justice}

The most prevalent conflicts within the community of Tulehu are disputes over land ownership, land demarcation, harvest rights, defamation, and theft; cases of murder are very few and rare. When conflict occurs, there are several strategies implemented by the community of Tulehu to access justice. These

${ }^{8}$ Ibid.; Ziwar Effendi, Hukum Adat Ambon Lease [Customary Law of Ambon Lease], First Edition, (Jakarta: vvPradnya Paramita, 1987).

${ }^{9}$ Ibid. 
strategies are established by the community and have several phases, namely: naming, blaming, and claiming ${ }^{10}$. In "naming" phase, Tulehu citizens who become a party in a particular case, feel the loss suffered. Then, the experience or feel the loss find the cause or party that caused the loss - at this phase, there was the so-called "blaming".

During the "blaming" phase, when the parties to a conflict to resolve their cases and make decisions that satisfy the parties, then the conflict is finished. But when the conversation turns perceived conflict between the parties reached an impasse, the third party involved Nader and Todd call the involvement of the third party as the third phase in the escalation of the conflict or also known as the 'dispute' phase. The action to involve third parties or intermediaries ${ }^{11}$ in dispute cases within the community of Tulehu is their strategy to reach a settlement. Intermediaries mentioned here may be a notable indigenous leader - especially the raja (head of the village) andreligious leaders such as imam/ worship leader of a mosque.

The intermediary strategies are various; First, through a custom court. If the parties to the dispute - whether it's due to the ownership of land, crops, land boundaries, or slander or infidelity - feel that their problems can not be resolved between the parties, then the parties brought the case to court or lodge customs.

The proceedings of the custom court are open to general public. The raja of Tulehu, secretary of the village, members of the village council (Badan Saniri) act as judges. A verdict from the custom court is not only to reconcile the issue, but also to provide sanctions for those found guilty. The village assembly in Tulehu once issued a decree which specifies which party is wrong and which party is right. These trials are not customarily located at the office of the head of the village or in the court building; these trials usually take place in Baileo/ traditional meeting house.

The procedures for conducting the custom trial begin with the summoning of the parties to a dispute. When the parties arrived, they are directed by the judge to reach a settlement. If both parties, however, cannot settle the claim, then it will go into the next stage, namely the trial. Proceedings in the custom court itself are similar to those in the legal court in accordance to the criminal procedure codes (KUHAP). The witnesses and defendants will be summoned, evidence will be presented, testimonies will be heard and examined, etc. After the judges decide that enough testimonies and evidences presented, they will deliberate - usually the head judge will consult other judges on the bench - and ultimately reach a verdict.

${ }^{10}$ William L.F. Felstiner, Richard L. Abel, and Austin Sarat, "The Emergence and Transformation of Disputes: Naming, Blaming, Claiming..." in Law and Society Review, Vol 15: 3-4, (1980/1981); Ward Berenschot and Adriaan Bedner, ..Access to Justice:...., p. 3-38.

${ }^{11}$ Ibid. 


\section{The Kaul (Vow)}

Custom court is not the only solution. The verdict of an custom trial may not be accepted by one or all of the parties to a dispute. In cases where the parties are not satisfied with the decision of the trial customary, the parties are entitled to apply for kaul.

Kaul is an action taken those who feel their rights are marred or harmed, to prove his innocence or to prove that the disputed object was actually hers. Kaul can be conducted after the trial custom made (if the verdict is not fulfilled a sense of justice of the parties), either in person - whenever needed-with the help of the local priest or cleric and usually at Idhul Adha (kaul negeri/public kaul ${ }^{12}$. The differences between private kaul with public kaul are the time and location of execution. Private kaul can be carried out anytime depending on the needs of disputing parties. The location of a private kaul is usually on the disputed land or in a mosque. On the other hand, a public kaul is performed by the disputing parties in public - in the office of local government. The time is also specific, namely on the evening of the feast of Idhul Adha. The disputing parties will come to local clerics or religious leader and bring animals such as goats, chickens, or pigeons with the intention to settle their dispute.

The action of kaul can be performed by way of slaughtering animals or by the reading of Surah Yassin. Animals to be slaughtered for the kaul are goats, pigeons, or chickens, in accordance to the severity of each case. Kaul which slaughters pigeon or chicken is a minor kaul. On the other hand, kaul which slaughters goats is a kaul with the most severe cases. Meat from slaughtered animals would then be handed over to the poor ${ }^{13}$.

The proceedings of a kaul and its ceremony are witnessed and led by the local clergy. Cleric here is the worship leaders of the mosque. According to the king of Tulehu, a worship leader of a mosque who leads the procession of a kaul must have extensive knowledge of religion, charisma, good behavior, an influence in the community, and must come from the descendants of clerics ${ }^{14}$.

In relation to the position of a religious leader and king in the ceremony of a kaul, it is interesting if we associate with the paper of Prof TO Ihromi ${ }^{15}$ in which he mentioned that within the implementation of customary law, the parties deemed to have authority and be obeyed by the citizens of the community are traditional leaders, local leaders, as well as local religious leaders. All of whom are "informal leaders, who are recognized by the local community, can voice norm so as to measure, how much a violation of norms and what should be required to offenders who have violated so that it can be straightened out again."

Below are some examples of cases which were resolved by a kaul. First example is a case in the 1960s, a dispute over land ownership. At first a claim Maluku],..

${ }^{12}$ Topo Santoso et al., .. [Customary Criminal Dispute Resolution of Indigenous Peoples in Central

${ }^{13}$ Ibid.

${ }^{14}$ Ibid.

15 Tapi Omas Ihromi, Kata Pengantar [Foreword] in T.O. Ihromi, ed., Antropology Hukum [Anthropology of Law], (Jakarta: Yayasan Obor Indonesia, 1993), p. 1-43. 
was brought before the customary court to obtain a fair settlement. Apparently customary court gave judgment in favor of the Y. Party X as opposed to Y felt that the ruling party did not benefit him. $\mathrm{X}$ is a woman who worked as a civil servant and held high office; she also had access to the district court. She then filed the case to the district court.

Due to her access to the local district court, $X$ went on to win the case and the judge ruled in her favor. Y, who was the winning party in custom court, felt aggrieved. Y then proceeded by executing a kaul. Within 5 years to 10 years after the kaul, a series of events happened which were suggested to be the sanctions imposed to the family of X due to the kaul of Y performed; for example: the death of parents, younger siblings, even children X sequentially for 5-10 years. The number of family members from children to younger siblings who died ${ }^{16}$.

The existing relatives of $\mathrm{X}$ came to an agreement and they apologized to the family of Y. They said that they were not involved and it was claimed that their parents were involved in a covenant with God. The family of X begged the family of $Y$ for forgiveness and returned the disputed land. However, the family of Y would not accept the land because they have forgiven sincerely. As a consequence the disputed land is now abandoned.

In the aforementioned dispute case, both party $\mathrm{X}$ and $\mathrm{Y}$ initially had equal opportunities to bring their case into the adat court and get the win-win solution. But, since $\mathrm{X}$ was not satisfied with the verdict of the custom trial in which Y won the case, she then brought litigation against Y before the district court. Because $X$ had better access to the state law than that of $Y$, she then won the district trial. To prove her innocence and restore dignity which was injured due to the action of $X$, party $Y$ chose the mechanism of customary law because she had access to this legal system. Party Y took a kaul as a last resort to restore her good name in the public eye.

Why did Y choose the action of a kaul? First, Y had better access to the system of customary law than to the state law. The opposing party, X, had better access to the law of the state due to her connection with the elite in the state judicial system - Bourdieu coined this type of power connection as 'social capital'. Second, the intention of Y in executing a kaul is also to restore her social status and good name. Insult or libel committed in public by offenders of customary law is considered as a severe breach of tradition. For Y, the action of $\mathrm{X}$ also injured Y's sense of justice because X's decision to submit the case before the district court was taken with the intention to embarrass her ${ }^{17}$.

Another major case settled by a kaul occurred in 1970. A woman, let's call her Z, had a child aged 5-6 year old. This child had a gold necklace. Then, the necklace was stored in a closet; however, $\mathrm{Z}$ forgot that she had stored away the necklace. She then accused her neighbor - let's call the neighbor P - of stealing Maluku],..

${ }^{16}$ Topo Santoso et al., .. [Customary Criminal Dispute Resolution of Indigenous Peoples in Central

${ }^{17}$ Tapi Omas Ihromi, Beberapa Catatan mengenai Metode Kasus Sengketa yang Digunakan dalam Antropologi Hukum [Some Notes on Methods of Dispute Cases Used in Anthropology of Law] in T.O. Ihromi, ed., Bunga Rampai Antropologi Hukum [Compilation of Anthropology of Law], (Jakarta: Yayasan Obor Indonesia, 1993), p. 194-213. 
her child's necklace. P was eventually detained by police for several days. P could only cry behind bars. Several days later P was released by police from jail. $\mathrm{P}$ then carried out a kaul in the presence of clergies. In other words, $\mathrm{p}$ chose a dispute resolution mechanism based on customary law, not through the state law, to prove her innocence ${ }^{18}$.

Four years after the kaul, the entire family of $\mathrm{Z}$ died. This was then followed by the death of her younger siblings. A man, who was the husband of Z's maternal aunt, believed that the chain of unfortunate events that befell his relatives was a consequence of Z's wrongful allegation against P. Consequently, it was suggested that $\mathrm{Z}$ had been stricken because of the kaul taken by P. At the end, Z's uncle apologized to P, the victim of slander by Z. Fortunately, P was to forgive him and his family. It is told that the man was then given drinking water that had been prayed upon by P and by some clergies; thus the end of the curse suffered by the family ${ }^{19}$.

In this example, party $\mathrm{P}$ felt the need to restore her rights and status, once vilified by Z, in society. P regarded taking a kaul as a mechanism of dispute settlement which carried severe penalties according the standard of the local community, as well as a binding one. The clergies who witnessed the kaul of $\mathrm{P}$ were the intermediaries.

The model of dispute resolution by performing a kaul, which is used by the Tulehu community to access justice, is not only carried out in the past. According to the information from raja of Tulehu himself, around two months before this study was carried out (it was conducted in February 2011) there had been a murder case in Ambon District Court. The defendant is known as Ridwan Orella ${ }^{20}$.

Although the criminal proceedings to be fully implemented, there was a distinctive feature in this particular trial. On the first day of the hearing many people came, from both the defendant's and the victim's side. This group of people carried a white colored chicken. Although the criminal proceedings to be fully implemented According to them, the kaul was a way to prove whether the accused was guilty or not. It is their belief that if the defendant was guilty, due to the Kaul taken, he would die. However, if the defendant was not guilty, then all parties involved in this custom judicial process would be affected as a result of the $\mathrm{kaul}^{21}$.

This group of people also demanded the slaughtering of the chicken to be performed in the courtroom. A commotion ensued and the demand was rejected by the head judge because it was not regulated in the procedures of state law. At the end they agreed that the slaughtering was carried out outside the courtroom. ${ }^{22}$ Maluku],..

${ }^{18}$ Topo Santoso et al., .. [Customary Criminal Dispute Resolution of Indigenous Peoples in Central
${ }^{19} \mathrm{Ibid}$.
${ }^{20}$ Ibid.
${ }^{21}$ Ibid.
${ }^{22}$ Ibid. 
As with previous cases, kaul is once again deemed to be one of the mechanisms of Tulehu community members to access justice if they feel that their social, cultural, and symbolical capital ${ }^{23}$ would not assist them in dealing with their opposing party. On the other hand, the opposing party may utilize the capital they have at hand, including a better access to the laws of the state, to obtain what they perceive as justice. In the courtroom of the aforementioned murder cases, there was a contestation between customary law and the state law in the form of attempt to execute the mechanism of kaul inside the courtroom of the district court - which is, in fact, a property of the state - when the first hearing took place.

\section{Conclusion}

In relation to dispute resolution mechanisms, the choice of the model and the legal system to be used by all parties involved depends on their capital. This capital - social, cultural, symbolical - determines the abilities of the party to access justice. A party with capital in the form of knowledge of the state law and a close association with the elite in the state judicial system would choose legal settlement through state court of law that they are familiar with. Conversely, those with capital in the form of knowledge of customary law, have little understanding of the state law, and do not have a good connection with law enforcement officers - in the context of state law - would submit their claim to indigenous leaders and clergies.

The community of Tulehu considers a dispute settlement model based on customary law satisfying for their sense of justice. As can be seen in the three cases described previously, although some cases had entered the realm of the state law, the injured party chose the mechanism of 'custom court' or a kaul. A kaul can even be regarded as evidence of contestation between indigenous law with state law, where the former has religious significance - from the place a kaul takes place or one of the forms of kaul which is the reading of Surah Yassin.

The kaul mechanism is one of the ways for members of the Tulehu community to access justice. This method is adopted when a resident of Tulehu feels that their 'social, cultural, and symbolical capital'24 is of no match to those of the opposing party in a dispute case. In other words, kaul or custom court is chosen as a means of settling dispute by the people of Tulehu when they are aware of the inequality of power between themselves and the other party.

Another interesting point in the dispute resolution mechanism within the community of Tulehu is the presence of custom trial. This traditional trial provides the opportunity for all parties involved to claim and counter claim and to present evidence and counter evidence. Social relations are sought to be maintained in the case of a dispute at custom trial by giving equal opportunity for all parties to be heard. However, the decision of custom trial is not legally

\footnotetext{
${ }^{23}$ Ward Berenschot and Adriaan Bedner, ..Access to Justice:...., p. 3-38.

${ }^{24}$ Ibid.
} 
binding, as evidenced by efforts taken by losing party to litigate a case before the district court.

In the context of cases of minor offenses, such as wrongful use of plantation land and the violation of SASI (a historic family of institutions, laws, and ritual practices that regulated access to fields, reefs, and rivers in the Maluku Islands), custom session mechanism should be developed to reduce the burden on state courts. There needs to be some sort of further research and training for custom trial judges to handle cases in a more professional and sense of justice. As for severe cases such as murder, however, criminal enforcement of State (Criminal Code) remain to be implemented.

\section{Bibliography}

\section{Books}

Benda-Beckmann, F. and K, von. "Transformation and Change in Minangkabau Adat" in LL. Thomas and F. von Benda-Beckmann (ed). Change and Continuity in Minangkabau: Local, Regional and Historical Perspectives. Athens: Ohio University Monographs in International Studies No 71.

Nader, Laura, and G.F. Todd Jr. (ed). Dispute Process-Law in Ten Societies. Columbia: Columbia University Press, 1978.

Nader, Laura. The ADR Explosion: The Implications of Rhetoric in Legal Reform. Windsor Yearbook of Access to Justice, 1989.

Tapi Omas Ihromi. Kata Pengantar [Foreword] in T.O. Ihromi (ed.) Antropologi Hukum [Anthropology of Law]. Jakarta: Yayasan Obor Indonesia, 1993.

Tapi Omas Ihromi. Beberapa Catatan mengenai Metode Kasus Sengketa yang Digunakan dalam Antropologi Hukum [Some Notes on Methods of Dispute Cases Used in Anthropology of Law] in T.O. Ihromi (ed.). Bunga Rampai Antropologi Hukum [Compilation of Anthropology of Law]. Jakarta: Yayasan Obor Indonesia, 1993.

Thomas Carothers. Promoting the Rule of Law Abroad: In Search of Knowledge. Washington: Carnegie Endowment for International Peace, 2006.

Ziwar Effendi. Hukum Adat Ambon Lease. [Customary Law of Ambon Lease]. Jakarta: Pradnya Paramita, First Edition, 1987.

\section{Journal Article/Reports}

Commission on Legal Empowerment of the Poor (CLEP). Report of the Commission on Legal Empowerment of the Poor. UNDP, 2007.

Bappenas Policy Recommendation - VVI Leiden tentang Kartu Tanda Penduduk dan Akses terhadap Keadilan. [VVI Leiden on Identity Cards and Access to Justice]. Jakarta: Bappenas, April 2010.

Topo Santoso et al. Research Report. Penyelesaian Sengketa Pidana Adat di Maluku Tengah [Customary Criminal Dispute Resolution of Indigenous Peoples in Central Maluku]. DRPM UI: Depok, 2011. 
Ward Berenschot dan Adriaan Bedner. Akses terhadap Keadilan, Sebuah Pengantar tentang Perjuangan Indonesia Menjadikan Hukum Bekerja untuk Semua Orang [Access to Justice: An Introduction to Indonesia's Struggle to Make the Law Work for Everyone] in Akses terhadap Keadilan [Access to Justice]. Jakarta: KITLV, HuMa, VVI Leiden University, Epistema Institute, 2011.

William L.F. Felstiner; Richard L. Abel; Austin Sarat. The Emergence and Transformation of Disputes: Naming, Blaming, Claiming... in Law and Society Review. Vol 15:3-4 (1980/1981). 